\title{
Effects of Fertigation on Root and Plant Nutrient Distribution of Field Grown Tomato(Lycopersicon esculentum Mill.).
}

\author{
Y. Rimcharoen and S. Wonprasaid*
}

\begin{abstract}
Fertigation is widely adapted for tomato production in Thailand as it is an efficient method for fertilizer application. However, its mechanism, especially the influence on root and plant nutrient distribution which is the critical aspect for nutrient uptake, has been rarely reported. A field experiment was conducted during the dry season in 2013 to investigate the impact of fertigation on tomato root and plant nutrient distribution in the soil profile. Fertigation and conventional (solid) fertilizer application with the same amount of nutrients and duration of application were compared under drip irrigation system. The results showed that fertigation was more efficient than solid fertilizer application, resulting in better growth, higher fruit yield and fertilizer use efficiency. The results also indicated that fertigation had a better root system than solid fertilizer application. The roots under fertigation distributed more vertically and horizontally than those under solid fertilizer application. Fertigation produced more small roots $(0.01-1.00 \mathrm{~mm})$ and medium roots $(1.01-2.00 \mathrm{~mm})$ but less large roots $(2.01-3.00$ $\mathrm{mm}$ ) than solid fertilizer application. More distribution of available form of primary nutrients ( $\mathrm{N}, \mathrm{P}$ and $\mathrm{K}$ ) to root zone was also found under fertigation system.
\end{abstract}

Index Terms-Tomato, Fertigation, Root system, Plant nutrients

\section{I.INTRODUCTION}

Tomato is an important economic vegetable in Thailand. In 2012 , total growing area was about $6,280 \mathrm{ha}$ [1]. Its growing area is mainly in the Northeast. The average yield is very low $\left(20.7 \mathrm{t} \mathrm{ha}^{-1}\right)$ due to poor management practices, plant pests and unfavorable environmental conditions. Furrow irrigation system used to be a common practice for the tomato growers in this area. The major drawback of furrow irrigation is its ineffectiveness in the coarse texture soil with low water use efficiency. Drip irrigation as the most efficient irrigation method is rapidly expanding and highly recommended in this area.Beside water application, solid fertilizer application (common practice for farmers) in this area is ineffective. Leaching is the main fertilizer loss as the soil is sandy with low water holding capacity. Chanthai et al. [2] compared fertigation and solid fertilizer application for tomato production under drip irrigation system. They prevented leaching of fertilizer by controlling irrigated water at root zone and covered the soil with plastic sheet to prevent excessive rain fall.

Manuscript received May 9, 2016. This work was supported by Suranaree University of Technology Research Fund.

Y. Rimcharoen is a graduate student of Institute of Agricultural Technology, Suranaree University of Technology, Nakhon Ratchasima, 30000, Thailand

S. Wonprasaid* is with Institute of Agricultural Technology, Suranaree University of Technology, Nakhon Ratchasima, 30000, Thailand
They found that fertigation produced greater tomato yield and nutrient use efficiency than solid fertilizer application with the same amount of nutrients. In their experiment, fertilizer was applied only 2 times for the solid fertilizer application treatment while for fertigation treatment fertilizer was applied 8 times. The more efficiency of nutrient application under fertigation than under solid fertilizer application in their experiment would be the results of fertilizer application frequency and fertilizer application methods. They also demonstrated that fertigation allowed the plant to absorb and accumulate more nutrients in leaf tissues than solid fertilizer application. However, they did not examine the mechanism of fertigation that make it more efficient, especially its influence on root and plant nutrient distribution which is the critical aspect for nutrient uptake.

This study aimed to compare the efficiency of fertilizer application between fertigation and solid fertilizer application with the same amount of plant nutrients and frequency of application and to investigate the effects of fertigation on root and plant nutrient distribution in soil profile.

\section{II.MATERIAL AND METHODS}

The experiment was conducted during dry season in 2013 at Suranaree University of Technology Farm, Nakhon Ratchasima, Thailand. The mean annual temperature was 29.5 ${ }^{\circ} \mathrm{C}$ and the absolute maximum and minimum temperatures were 35.6 and $23.3{ }^{\circ} \mathrm{C}$ respectively. The experimental soil was texturally classified as sandy clay loam. Soil $\mathrm{pH}$ was 6.53 with an EC of $0.25 \mathrm{dSm}^{-1}$ and organic matter content of $1.18 \%$. Soil was medium in available phosphorus (14.12 $\left.\mathrm{mg} \mathrm{kg}^{-1}\right)$ and medium in exchangeable potassium $\left(59.1 \mathrm{mg} \mathrm{kg}^{-1}\right)$.

The treatments included fertigation and solid fertilizer application with the same amount of nutrients and duration of application, each treatment was replicated 4 times. Thirty-day-old seedlings of Hybrid tomato (cv. Perfect Gold 111) were transplanted to the field with the row spacing of $75 \mathrm{~cm}$ and plant spacing of $50 \mathrm{~cm}$. Drip irrigation was installed using drip line with $2 \mathrm{lh}^{-1}$ discharge rate emitters in each row.

The fertilizers used in both treatments were urea (46-0-0), potassium nitrate (13-0-46) and mono potassium phosphate (0-52-34). The fertilizers were applied weekly in 9 equal splits staring two weeks after tomatotransplanting. The level of fertilizer adopted in the present study was $150-50-100 \mathrm{~kg}$ $\mathrm{N}, \mathrm{P}_{2} \mathrm{O}_{5}, \mathrm{~K}_{2} \mathrm{O}$ ha $^{-1}$, which is the rate recommended based on soil test[3].

The amount of water to be applied each time was equivalent to the cumulative water requirement (ETc) of 15 $\mathrm{mm}$ which was according to the soil available water holding capacity $(11.4 \%)$. The ETc of tomato was calculated by the following equation: 


$$
\mathrm{ETc}=\mathrm{ETp} \times \mathrm{Kc}
$$

Where ETp is the potential evapotranspiration estimated based on the long-term average climatic data in this area and $\mathrm{Kc}$ is the crop coefficient.

Data on plant growth traits including plant height and stem diameter were recorded at weekly interval. Tomato fruits were harvested after 65 days after transplanting. Twenty plants per plot were selected randomly for the measurement of quantitative traits such as fruit number and fruit weight. Fertilizer use efficiency (FUE) was determined as a factor of total economic yield from all harvests divided by quantity of nutrient applied.

Root length density study was carried out at first flowering stage by sampling the roots with the $7 \mathrm{~cm}$ diameter soil auger at the depth of 0-10, 10-20 20-30, 30-40, 40-50, and 50-60 cm and at the lateral distance of 10 and $20 \mathrm{~cm}$ from the stem. The soils around the roots were washed off through jet of water[5], [6]. The root samples were distributed in to the trays containing a film of water and were scanned by the scanner (Skener Perf. V700), then the scanned pictures were analyzed by root analysis software (WinRHIZO Regular STD 4800) to determine root length density.

For nutrient distribution study, the soils were taken at the same depths and lateral distances as root sampling. $\mathrm{NH}_{4}{ }^{+}$and $\mathrm{NO}_{3}{ }^{-}$of all samples were analyzed by the Steam Distillation Method[7], while available $\mathrm{P}$ and exchangeable $\mathrm{K}$ were analyzedby Bray II and Ammonium Acetate method respectively.

\section{RESULTS}

\section{Tomato Growth, Fruit Yield and Fertilizer Use Efficiency.}

The statistical analysis revealed that fertilizer application methods resulted in different tomato growth and yield. Fertigation increased plant height, stem diameter, and dry weight over solid fertilizer application (TABLE I). Fertigation produced tomato yield $(42.6 \mathrm{t} / \mathrm{ha}$ ) higher than solid fertilizer application ( $35.4 \mathrm{t} / \mathrm{ha})$ by $20 \%$. Fertigation also resulted to higher tomato fruit weight than solid fertilizer application which was equal to 70.0 and $68.1 \mathrm{~g} /$ fruit respectively. Fertilizer use efficiency of $\mathrm{N}, \mathrm{P}$ and $\mathrm{K}$ was greater in fertigation treatment than solid fertilizer application treatment (TABLE I).

TABLE I

EFFECTS OF FERTILIZER APPLICATION ON TOMATO GROWTH, YIELD ANDNUTRIENTUSE EFFICIENCY.

\begin{tabular}{|c|c|c|c|c|c|c|c|}
\hline \multirow{2}{*}{ Treatments } & \multirow{2}{*}{$\begin{array}{c}\text { Plant height } \\
\text { (cm) }\end{array}$} & \multirow{2}{*}{$\begin{array}{c}\text { Total dry weight } \\
\left(\text { g plant }^{-1}\right)\end{array}$} & \multirow{2}{*}{$\begin{array}{l}\text { Fruit weight } \\
\quad \text { (g fruit }^{-1} \text { ) }\end{array}$} & \multirow{2}{*}{$\begin{array}{c}\text { Yield } \\
\left(\text { t ha }{ }^{-1}\right)\end{array}$} & \multicolumn{3}{|c|}{$\begin{array}{c}\text { FUE } \\
\left(\mathrm{kg} \mathrm{kg}^{-1}\right)\end{array}$} \\
\hline & & & & & $\mathbf{N}$ & $\mathbf{P}$ & $\mathbf{K}$ \\
\hline Solid fertilizer & $98 \pm 0.37^{*}$ & $90 \pm 0.11$ & $68.1 \pm 0.12$ & $35.4 \pm 3.6$ & $236 \pm 24$ & $708 \pm 72$ & $354 \pm 37$ \\
\hline Fertigation & $103 \pm 0.24$ & $109 \pm 0.05$ & $70.0 \pm 0.28$ & $42.6 \pm 7.1$ & $284 \pm 47$ & $852 \pm 142$ & $426 \pm 71$ \\
\hline
\end{tabular}

$*$ Values $=$ Mean \pm S.E.

\section{Root Length Density}

The root length density measurements at the distances of 10 and $20 \mathrm{~cm}$ from the stems showed that fertigation and solid fertilizer application application resulted in different root density at all levels of soil depths, except at the level of 50-60 $\mathrm{cm}$. which had little amount of roots (Fig 1). In both lateral distances from the stems $(10 \mathrm{~cm}, 20 \mathrm{~cm})$ the fertigation treatment had more density of roots than the solid fertilizer application treatment.

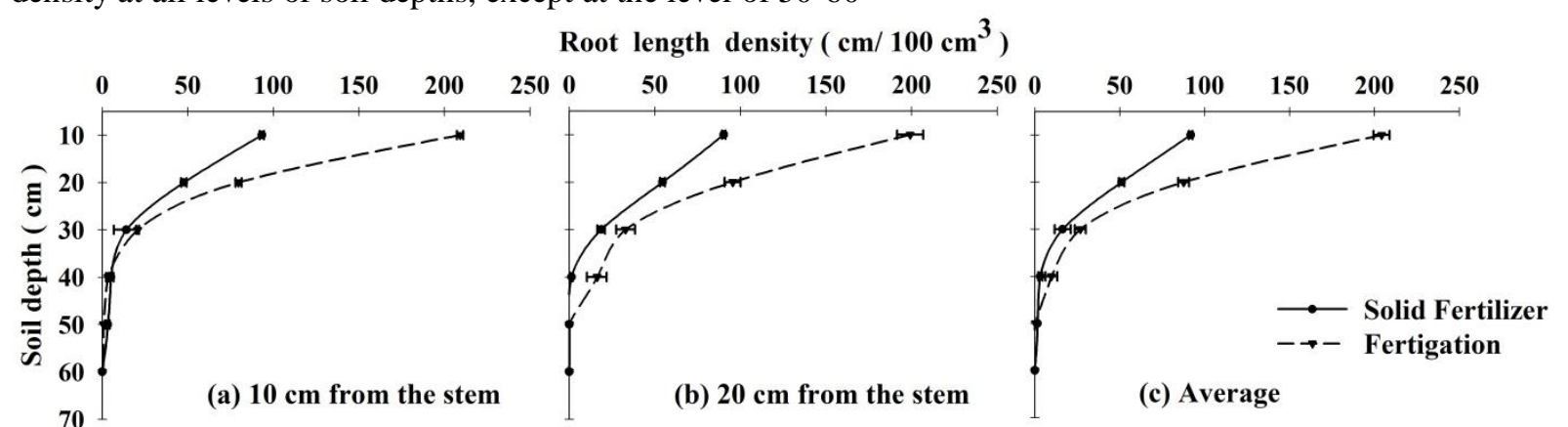

Fig.1.Effects of fertilizer application on total root length density of tomato.(Values = Mean \pm S.E.) was found that the fertigation and the solid fertilizer

This study not only measured the density of total roots but also the density of small roots (0:01 to 1:00 mm.), medium roots $(1: 01$ to $2: 00 \mathrm{~mm}$.) and large roots $(2: 10$ to $3: 00 \mathrm{~mm})$. It application 
resulted in different root density of each size. Fertigation achievedit was found that the solid fertilizer application yielded more more density of small roots and medium roots, but for large roots, density of the roots as shown in Figure 2.

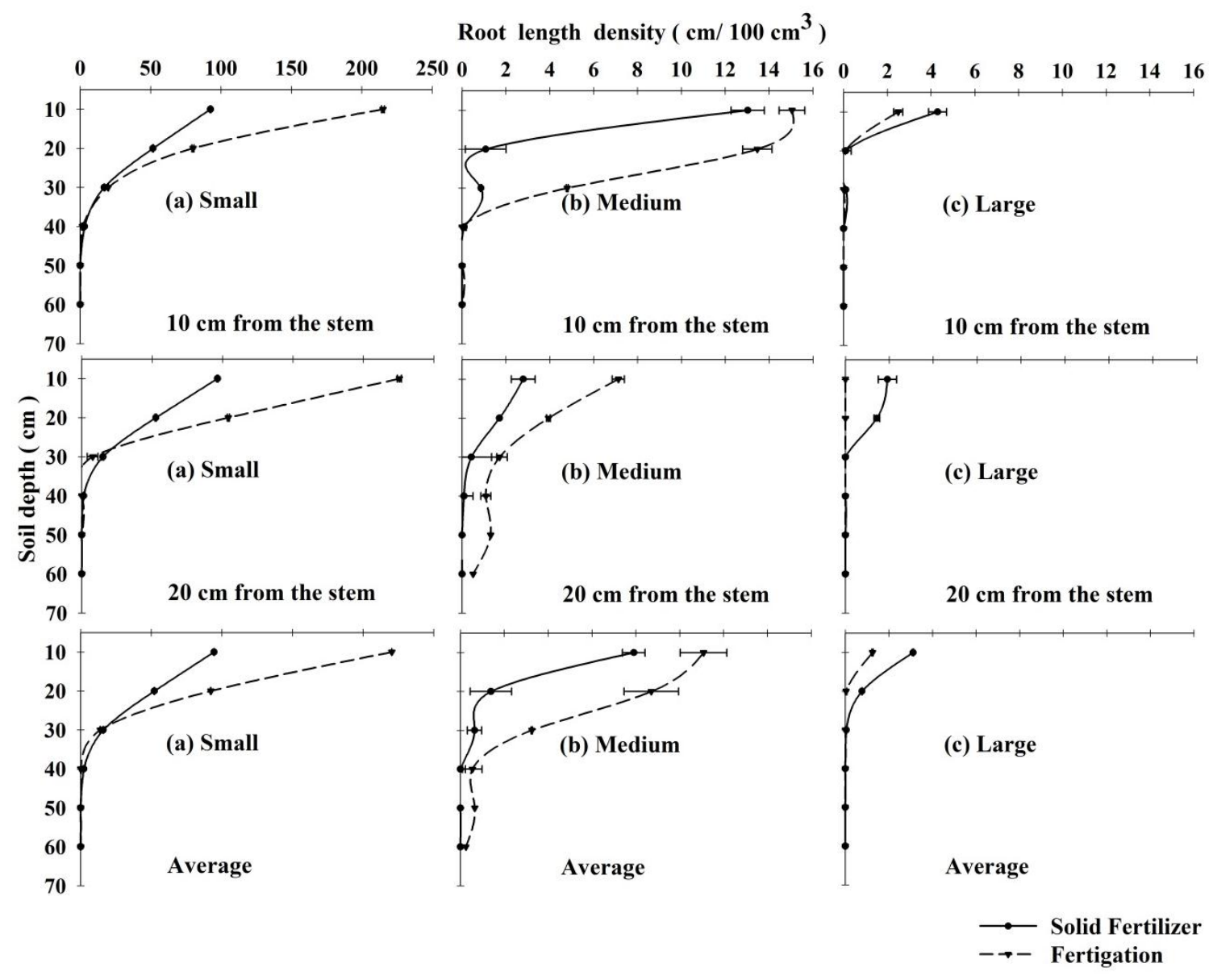

Fig.2.Effects of fertilizer application on root length density of different root sizes.(Values = Mean \pm S.E.)

\section{Plant Nutrient Distribution}

By comparing fertigation with solid fertilizer application with the same amount of plant nutrients, the study measured the amount of available nutrients(N, P and $\mathrm{K}$ ) after three days of fertilizer applicationduring the flowering of tomatoes.

\subsection{Nitrogen $(N)$}

$\mathrm{N}$ was applied in the form of urea in both methods. After 3 days of application, available $\mathrm{N}$ in the forms of nitrate $\left(\mathrm{NO}_{3}^{-}\right)$and ammonium $\left(\mathrm{NH}_{4}^{+}\right)$were analyzed at the distances of 10 and $20 \mathrm{~cm}$ from the stems and at the depths of 0 to $60 \mathrm{~cm}$ from the soil surface.

It was found that at $10 \mathrm{~cm}$ distance from the stems, available $\mathrm{N}$ was more with solid fertilizer application than fertigation only at the depth of $0-10 \mathrm{~cm}$ but at the deeper levels, available $\mathrm{N}$ was more with the fertigation than solid fertilizer application. At the distance of $20 \mathrm{~cm}$ from the stem, amount of available $\mathrm{N}$ was similar between fertigation and solid fertilizer application at the top soil $(0-10 \mathrm{~cm})$ but it was more in fertigation than solid fertilizer application at the deeper soil. The total amount of available $\mathrm{N}$ throughout the root zone was also higher in fertigation than solid fertilizer application except at the top soil (Fig. 3a).

\subsection{Phosphorus $(P)$}

By measuring the amount of available $\mathrm{P}$ in the soil profile, it was found that in both distances from the stems, the fertigation resulted in higher available $\mathrm{P}$ than the solid fertilizer application in all depths except at the top soil (0-10 $\mathrm{cm}$ ) where it was found that the solid fertilizer application had higher amount of available $\mathrm{P}$ than the fertigation(Fig. $3 b)$.

\subsection{Potassium (K)}

Distribution of exchangeable $\mathrm{K}$ in the soil was similar to $\mathrm{N}$ which was different between fertigation and solid fertilizer application (Fig. 3c). At the soil surface $(0-10 \mathrm{~cm})$ more exchangeable $\mathrm{K}$ was found under solid fertilizer application in both distances from the stems, but at all deeper soil profile, fertigation resulted to more exchangeable $\mathrm{K}$. 


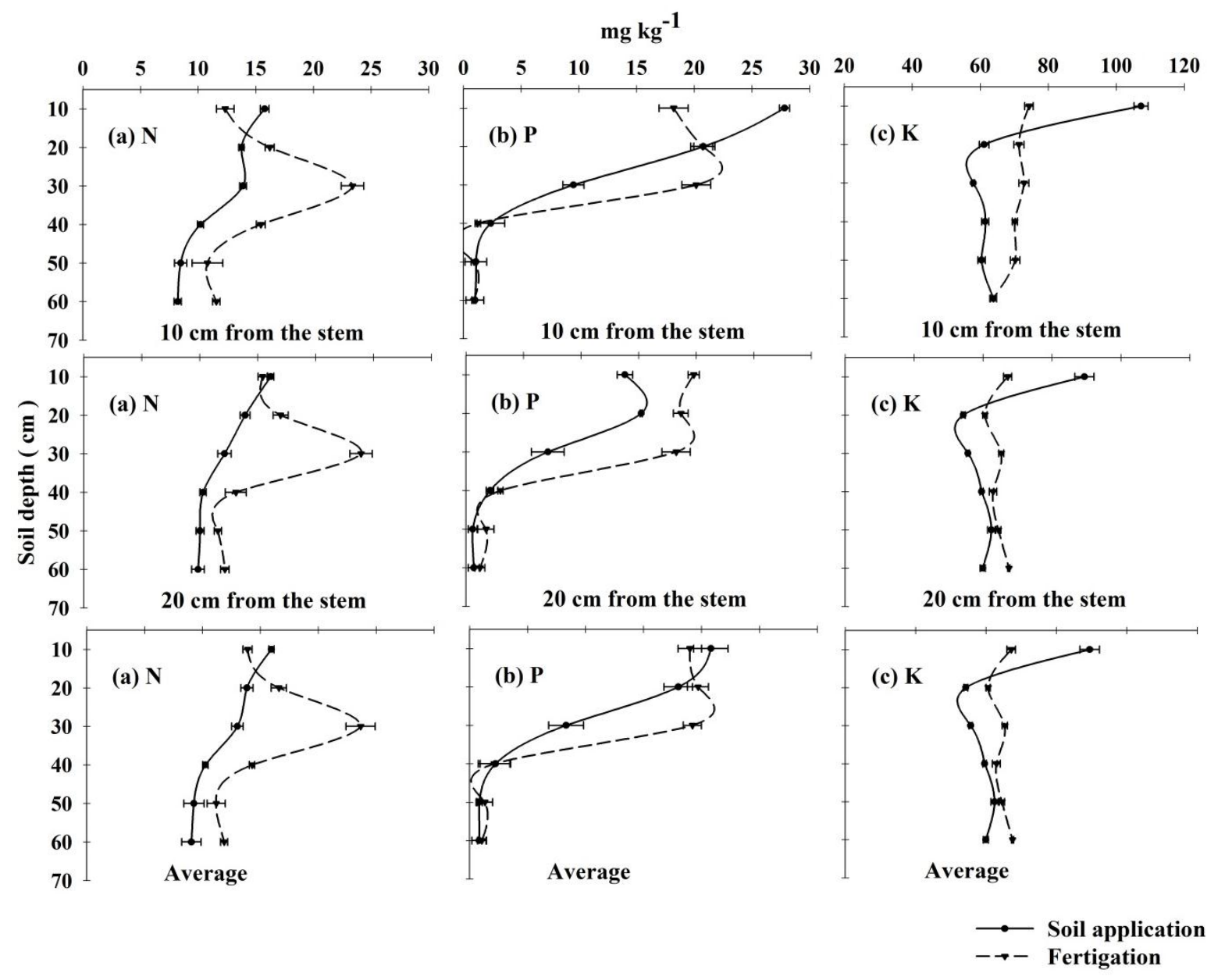

Fig.3.Effects of fertilizer application on availableN, $\mathrm{P}$ and Kdistribution in soil profile. (Values $=$ Mean \pm S.E.)

\section{DISCUSSION}

Fertigation system was effective in providing better fertilizer than the solid fertilizer application, with better growth and yield of tomatoes and higher fertilizer use efficiency. These results were consistent with the study of Chanthai et al. (2013) [2] who compared fertigation with solid fertilizer applicationunder the same environmental conditions and soil as this experiment. They reported that the fertigation promoted faster growth and resulted to more tomato dry matter and yield compared to solid fertilizer application. Badr et al. [8]studied the nutrient uptake and yield of tomatoesunder various methods of fertigation under drought conditions. They found that $100 \%$ of fertilizers application through irrigation system achieved the highest levels of the number of fruits per plant, the dry weight, yield and fertilizer use efficiency as compared to $100 \%$ solid fertilizer application or the combination of fertigation and solid fertilizer application (50\% each). These results were also coinciding with the study of Shedeed et al. [9] and Hebbar et al. [10] who found that fertigation of $\mathrm{N}, \mathrm{P}$ and $\mathrm{K}$ resulted in higher yield of tomato than solid fertilizer application by $33 \%$. Besides, there was a report that the fertigation system had higher rate of plant growth and higher yield than that of solid ferilizer application because there was more efficient use of fertilizers [11], especially $\mathrm{N}$ and $\mathrm{K}$.
This study found that the roots system were better under fertigation system. It resulted in more density of the root system collectively, both small and medium-sized roots, but for the large roots, it was found that solid fertilizer application had more density. Fertigation clearly promoted larger amount of small roots, and that these small roots were more critical to the absorption of water and nutrients than the larger rootsbecause the roots with smaller radius usually have higher different energy of the water between root surface and inside the roots than large roots. The results were so encouraging to see that the fertigation not only increased the quantity of all roots, it also added more roots that were able to absorb nutrients well. The results were consistent with Hartz[12]who reported that the K-planted tomatoes in a drip irrigation system not only increased productivity, it also increased the amount of nutrient uptake by roots.

Fertigation system led to better lateral and horizontal distribution of soil nutrients than the solid fertilizer application. It resulted in more distribution of fertilizer $\mathrm{N}$ and faster transformation of urea into ammonium and nitrate than solid fertilizer application. The rapid change from urea to ammonium and nitrate in fertigation treatment might be due to the urea input to the irrigation system was dissolved and spread according to soil moisture[13]leading to the exposure to microorganisms that stimulated the conversion of urea to ammonia and nitrate faster than solid fertilizer application. 
From the experimental work of solid fertilizer application and fertigation at $0 \%, 50 \%, 75 \%$ and $100 \%$, it showed that $100 \%$ of fertigation had the most quantity of $\mathrm{NO}_{3}^{-}$in the soil at the depth of $0-40 \mathrm{~cm}$ from the soil surface [8], which is in agreement with this experiment. Normally distribution of $\mathrm{K}$ in the soil is slower than $\mathrm{N}$ as it is usually adsorbed to surface of mineral clay. However, under fertigation the $\mathrm{K}$ distribution was more as it was dissolved to very low concentration and moved with water to both horizontal and vertical sides. Fertigation also promoted more distribution of $\mathrm{P}$ in soil profile. $\mathrm{P}$ is usually adsorbed and hold easily in most soils [14], it tends to react quickly to the different minerals present in the soil, making it difficult to move and causing majority of surface residue. In this experiment, the fertigation made more $\mathrm{P}$ spread in both depth and lateral distribution compared to solid fertilizer application. There was a report which supported that the $\mathrm{P}$ application through irrigation system could make P move 5-10 times faster than solid fertilizer application [15].

The study of Hebbar et al. [10]reported that fertigation can reduce the loss of $\mathrm{NO}_{3}{ }^{-}$and $\mathrm{K}^{+}$at the deeper level than the root zone which led to more available nutrients to plants in the root zone. This ledto more fertilizer use efficiency of fertigation than solid fertilizer application. However, in this experiment, loss of the soil fertilizer was limited because the experiment was done in the dry season and the applied water did not exceed the water holding capacity of the soil. Factors that made fertigation more efficient would be the distribution of the fertilizer and the better root system. These results were supported by Gardenas et al. [16]who reported that the application of fertilizers through irrigation system helped the plants get directly both the fertilizer and the water, and the distribution of fertilizers in the root zone enabled the plants to absorb the fertilizer more efficiently.

\section{CONCLUSION}

Fertigation system was an effective way to provide better fertilizer than the solid fertilizer application. Fertigation promoted growth and yield of tomato and higher fertilizer use efficiency which were associated with the roots and plant nutrients distribution in soil profile. Fertigation resulted in more density of the root system especially small and mediumsized roots. Fertigation also led to more vertical and horizontal distribution of available plant nutrients than the solid fertilizer application.

\section{ACKNOWLEDGEMENTS}

The authors wish to acknowledge the Suranaree University of Technology Farmfor providing the experimental field and materials.

\section{REFERENCES}

[1] Department of Agricultural Extension. "Statistical information of economic crop production" [Online]. http://www.oae.go.th. 2014.

[2] S. Chanthai, T. Machikowa, S.Wonprasaid, and N.Boonker."Effects offertigation, water applicationfrequency and soil amendment on tomato production"ActaHorticulturae ,vol. 984, 187-196, 2013. http://dx.doi.org/10.17660/ActaHortic.2013.984.20

[3] Department of Agriculture,"The use of fertilizers oncrops", Federation of Agricultural Cooperatives of Thailand, Bangkok, Thailand, 2005.
[4] R. G. Allen, L. S. Pereira, D. Raes, and M. Smith, "Crop evapotranspiration. Guidelines for computing crop water requirements," FAO, Ed. Rome, 1998.

[5] H. Ozier-Lafontaine, F. Lecompte, and J. F. Sillon, "Fractal analysis of the root architecture of Gliricidiasepium for the spatial prediction of root branching, size and mass: model development andevaluation in agroforestry" Plant Soil., vol. 209, pp. 167-179, 1999. http://dx.doi.org/10.1023/A:1004461130561

[6] S. G. K. Adiku, H. Ozier-Lafontaine, and T. Bajazet,"Patterns of root growth and water uptake of a maize-cowpea mixture grown under greenhouse conditions" Plant andSoil.,vol. 235, pp. 85-94, .2001.

[7] J. M. Bremner,"Nitrogen-total" In: Methods of soil analysis. Part 3" Chemical methods-SSSA book series no 5, D. L. Sparks et al, Ed. Soil Science Society of America, pp. 1085-1121, 1996.

[8] M. A. Badr, S. D. Abou Hussein, and W. A. EI-Tohamy, "Nutrient uptake and yield of tomatounder various method of fertilizer application and levels of fertigation in arid lands" GesundePflanzen. J., Vol. 62, pp. 11-19, 2010.

[9] S. I. Shedeed, S. M. Zaghloul and A. A. Yassen, "Effect of method and rate of fertilizer application under drip irrigation on yield and nutrient uptake by tomato" Ozean J. Appl. Sci., vol. 2, pp. 139-147, 2009.

[10] S. S. Hebbar, B. K. Ramachandrappa, H. V. Nanjappa, and M. Prabhakar, "Studies on NPK drip fertigation in field grown tomato (Lycopersiconesculentum Mill.)" J. Europ Agronomy., vol. 21, pp. 117127, 2004.

http://dx.doi.org/10.1016/S1161-0301(03)00091-1

[11] R. S. Malik, K. Kumar, and A. R. Bhandari, "Effect of urea application through drip irrigation systemon nitrate distribution in loamy sand soils and pea yield" J. Indian Soc. Soil Sci., vol. 42, pp. 6-10, 1994.

[12] T. Hartz, "Efficient fertigation management for drip-irrigated processing tomatoes" UCCE Vegetable Notes Fresno, Tulare and Kings Counties, Ed. University of California Cooperative Extension, vol. 4, pp. 2-3. 2008.

[13] E. T. Craswell, and P. L. G. Vlek, "Fate of fertilizer nitrogen applied to wetland rice" Nitrogen and rice, Symposium proceedings, Ed. J. R. Freney et al, pp. 175-193, Philippines: International Rice Research Institute, 1978.

[14] I. Papadopoulos, and M. Ristimaki Leena, "Nitrogen and phosphorus fertigation of tomato and eggplant" In Proc. of the HIS. Belgium, 2-9 Aug., 1998.

[15] R. S. Rauschkolb, D. E. Rolston, R. J. Miller, A. B. Carlton, and R. G. Burau, "Phosphorus fertilization with drip irrigation" Soil Sci. Soc. Am. J., vol. 40, pp. 68-72, 1976. http://dx.doi.org/10.2136/sssaj1976.03615995004000010021x

[16] A. Gardenas, J. W. Hopmans, B. R. Hanson, and J. Simunek, "Twodimensional modeling of nitrate leaching for difference fertigation strategies under micro-irrigation" Agric. Water. Manage., vol. 74, pp. 219-249, 2005. http://dx.doi.org/10.1016/j.agwat.2004.11.011 